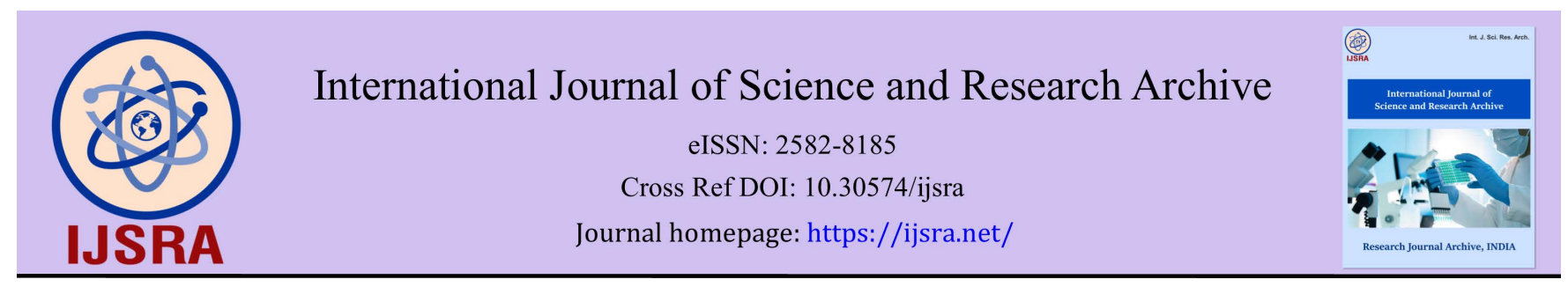

(RESEARCh ARTICLE)

\title{
Determination of total flavonoid, antioxidant, active constituents and liver function
}

\section{enzyme of Plantago laceolata aqueous extract}

\author{
Farah T. 0. AL-Jumaili * \\ Collage of Biotechnology, Al-Nahrain University, Baghdad, Iraq.
}

International Journal of Science and Research Archive, 2022, 05(01), 059-066

Publication history: Received on 25 December 2021; revised on 03 February 2022; accepted on 05 February 2022

Article DOI: https://doi.org/10.30574/ijsra.2022.5.1.0034

\begin{abstract}
Plantago laceolata considered as an ancient herb promising plant. In this work, the target of the study was designed to estimate total flavonoids, anti-oxidant and chemical composition of Plantago laceolata aqueous extract in vitro. Total flavonoids content was; evaluated in the extract, and it was $317.0000 \pm 9.64365 \mathrm{mg} / \mathrm{ml}$. also, anti-oxidant activity of Plantago laceolata aqueous extract in vitro was assessed in vitro via evaluation of reductive ability. At all concentrations of plant extract tested $(0.02,0.04,0.08,0.16,0.32$ and $0.64 \mathrm{mg} / \mathrm{ml})$ in reductive ability; the absorbance was increase significantly in all dependent concentration manner. also, the aqueous plant extract was increase significantly The results of chemical composition of plant showed contain Tannins, polysaccharide, Alkaloids, Flavonoids and Polyphenolic Compounds. Also plant extracts counteract the damage caused by methotrexate drug through the reduction in liver enzymes GOT, GPT and ALP in all groups of mice the results of interactions indicated the ability of plant to modulating harmful effects of the drug in liver and its enzymes when administration to albino mice male in $200 \mathrm{mg} / \mathrm{kg}$.
\end{abstract}

Keywords: Plantago laceolata; Anti-Oxidant; Chemical Composition; Reductive Ability; Alkaloids; Methotrexate

\section{Introduction}

Among the medicinal herbs species of therapeutic interest is included P. lanceolata. which is a type of the genus in the family named Plantaginaceae originated from Europe, commonly spread throughout the world. Plantago lanceolata. is a common recurrent weed, It is inborn in herb places on basic or neutral soils [1].

Plantago lanceolata, was grows to a tall about $40-60 \mathrm{~cm}$ and yields a rosette of leaves, sometimes up to $50 \mathrm{~cm}$, in tall [2]. The size of the plantago be determined by the growth habitats.

The complex chemical composition of P. lanceolata L. species is represented by a series of categories of substances, among which the main components are: iridoid glycosides, polysaccharides (plantaglucide, glucomannan), flavonoids and flavone glycosides, phenolic carboxylic acids, alkaloids (indicain, plantagonin), terpenoids (loliolide, ursolic acid, oleanolic acid. [3]. As a result of the presence of active metabolites, Plantago major L. is used in cosmetic and pharmaceutical industries. Treating dermal diseases, anti-diarrhea, anti-cancer and antibacterial activates have been described in different sources as some of the health benefits of this plant [4]. which concluded that plant had beneficial effect on health.

Several studies develop methods for investigating the antioxidant properties of different, such as: Ferric Reducing Antioxidant Power (FRAP) assay, Trolox Equivalent Antioxidant Capacity (TEAC), DPPH (diphenylp-picrylhydrazyl

\footnotetext{
* Corresponding author: Farah T. 0. AL-Jumaili

Collage of Biotechnology, Al-Nahrain University, Baghdad, Iraq.

Copyright (C) 2022 Author(s) retain the copyright of this article. This article is published under the terms of the Creative Commons Attribution Liscense 4.0.
} 
radical), oxygen radical absorbance capacity (ORAC), chemiluminescence (CL), to name a few [5]. These methods are being applied by the food, pharmaceutical and cosmetic industries.

The long-term problem of MTX stay the basic causes of worried for both patients and therapists. Then, new methods to improve patients' tolerance and decrease MTX side effects are necessary needed [6]

This study had been approved out to estimate the effects of Aqueous extract of Plantago lanceolata extract against MTXinduced hepatic damage in mice.

\section{Material and methods}

\subsection{Plant collection and identification}

The aerial part of the plantago was collected from the local markets during October (2020), which had been identified by National Herbarium of Iraq.

\subsection{Plant extract Preparation}

Aqueous extract of Plantago lanceolata was obtained according to. [7] Fifty grams of the plant aerial parts powdered and extracted with hot distilled water $(250 \mathrm{ml}) 65^{\circ} \mathrm{C}$ for 1 hour in soxhlet device The plant extract solution was dryness under under reduction pressure to concentrated in a rotary evaporator to yield crude dried plant extract at $37^{\circ} \mathrm{C}$ until dryness, then frozen at $-20^{\circ} \mathrm{C}$ until use the essential concentration.

\subsection{Determination of Total Flavonoids}

Total flavonoids contented was spectrophoto-chemically resolute in the P. lanceolata aqueous extract by way of rutin standard equal by $\mathrm{ALCl}_{3}$ colorimetric method [8].

The aqueous plant extract in weight (3.2 $\mathrm{mg}$ ) was once as soon as dissolved among five $\mathrm{ml}$ in regard to fifty \% methanol, accompanied with the aid of addition concerning one ml concerning a five percentage (w/v) (NaNo3) solution. After six minutes, one $\mathrm{ml}$ involving a ten percentage $(\mathrm{w} / \mathrm{v})$ aluminium chloride answer was once brought yet the combination used to be allowed in accordance with remain because of a in addition five minutes before ten $\mathrm{ml}$ in regard to a ten \% $(\mathrm{w} / \mathrm{v}) \mathrm{NaOH}$ reply used to be added. The mixture used to be committed up in imitation of fifty $\mathrm{ml}$ along DW but mixed well. Then the absorbance used to be modest at $450 \mathrm{~nm}$ with a spectrometer below fifteen min. A similar process used to be applied in accordance with vii after concentrations (two and half, five, ten, twenty, forty since eighty $\mu \mathrm{g}$ ) concerning rutin as like standard, yet ancient in imitation of put together standard curve.

\subsection{Determination the active chemical constituent in plant [9]}

\subsubsection{Detection of Tannins tests}

The one \% Lead acetate solution have been added to the aqueous plant extract. A gelatinous or white precipitate have been made that the presence of tannins.

\subsubsection{Detection of polysaccharides}

One $\mathrm{ml}$ of the aqueous plant extract was mixed with two $\mathrm{ml}$ of the Benedict reagent, then put the mixture in a boiling water bath for five minutes and left to cool. The red deposit indicated that a presence of polysaccharides.

\subsubsection{Detection of alkaloids (Dragangroff test)}

A solution of $60 \mathrm{mg}$ of Bismuth sub-nitrate have been dissolved in $0.2 \mathrm{ml} \mathrm{HCl}$ (solution A) and Solution B contains 600 mg potassium iodide in one $\mathrm{ml}$ D.W The solution $\mathrm{A}+\mathrm{B}$ were mixed and additional to the plant aqueous extract, an orange to brown color will detected expression the founded of alkaloids.

\subsubsection{Detection of the Saponins}

The detection process was happened by mixing the solution of the plant aqueous extract well. Formation of foam at the top of the extract showed of saponins. 


\subsubsection{Detection of Flavonoids}

This test was prepared by using Sodium hydroxide solution had been mixed with restricted amount of plant extract solutions and left, a bright yellow color was showed that appeared of flavonoids.

\subsubsection{Detection of Polyphenolic Compounds}

Three \% ferric chloride $\left(\mathrm{FeCl}_{3}\right)$ solution have been added to the plant aqueous extract solution a brown deposition will be show.

\subsection{Determination of free radical scavenging assay method}

This method was complete by estimate the reductive ability by using [10], used to be adopted in conformity with consider the reductive ability, inside namely $1 \mathrm{ml}$ regarding every attention of the drive into put off $[0.02,0.04,0.08$, $0.16,0.32$ yet $0.64 \mathrm{mg} / \mathrm{ml}$ ] used to be combined collectively along one $\mathrm{ml}$ as regards $0.2 \mathrm{M}$ phosphate clink ( $\mathrm{pH} 6.6$ ) after one and half $\mathrm{ml}$ concerning one \% potassium ferricyanide, afterward then incubated at $50^{\circ} \mathrm{C}$ due to the fact on 20 minutes. Then, $1 \mathrm{ml}$ related to ten \% trichloroacetic sour style was once introduced below the combination after quit the reaction. The mixture was once centrifuged due to the fact $\mathrm{x}$ minutes at $3000 \mathrm{rpm}$, but $2.5 \mathrm{ml}$ above the supernatant used to be mixed including two $\mathrm{ml}$ of distilled water or $0.5 \mathrm{ml}$ over anew.

\subsection{Determination the Liver protection ability of plant}

For enzymatic examined test, blood had been collected by heart puncture, which had been transported to small tubes (Eppendorf) and a permitted to clot at room temperature $37{ }^{5} \mathrm{C}$ for fifteen minutes, after that serum was parted by centrifugation at 3,000 rpm for about 10 minutes. The collected serum had been used for the determined of liver enzyme parameters [11], commercial kits (Randox Company) were used then liver was taken for histopathological examination.

\subsubsection{Animal's used in study}

Six to eight weeks aged Albino male mice 23-25 g, and were taken from the animale house of Biotechnology Research Center, Al-Nahrain University, animals were kept in cages (4 mice in each cage) were separated into three groups as indicated in Table 1.

Table 1 Groups of animals investigated in the Laboratory tests

\begin{tabular}{|l|c|c|}
\hline \multicolumn{1}{|c|}{ Type of interaction } & Dose $\mathbf{~ m g / k g}$ & number of animals \\
\hline Distilled water & -------- & 4 \\
\hline Methotrexate & 40 & 4 \\
\hline Plantago lanceolata & 200 & 4 \\
\hline Methotrexate + plantago plant & $40+200$ & 4 \\
\hline Total number of animals & & 16 \\
\hline
\end{tabular}

\subsection{Experimental design}

Animals were kept (four mice in one cage) with add libitum contact to water and food pellets. mice have been divided into four groups: The first group was treated with $200 \mathrm{mg} / \mathrm{kg}$ of plant extract, the second group was treated with 40 $\mathrm{mg} / \mathrm{kg}$ of methotrexated drug which was the product of Pharmacia Company (Belgium), the third group was treated with an interaction of $40 \mathrm{mg} / \mathrm{kg}$ methotrexate and $200 \mathrm{mg} / \mathrm{kg}$ plant extract, and the last group represent the control group (normal mice without any treatment). Each investigated group was injected intraperitoneally (i.p.) with a single dose per day $(0.1 \mathrm{~mL})$ of the tested material in 7 days. On day eight of the experiment the animals have been dissected to complete research calculations [12] 


\section{Results and discussion}

\subsection{Total flavonoid}

Total flavonoids content were spectrophoto-chemically determined in aqueous extract of $P$. lanceolata as rutin equivalent. The aqueous extract was present to contain $317.0000 \pm 9.64365 \mu \mathrm{g} / \mathrm{ml}$ flavonoids Such finding is agreement with a study carried out by [13].

Table 2 Total Flavonoid of Plantago lanceolata aqueous extract

\begin{tabular}{|c|c|}
\hline Total Flavonoid & Mean \pm Std \\
\hline Plantago lanceolata & $317.0000 \pm 9.64365$ \\
\hline
\end{tabular}

\subsection{Active chemical constituent in plant}

Determination active constituents of Plantago lanceolata aqueous extract showed that chemical composition of plant contain (Tannin, polysaccharide, alkaloid,flavonoid, polyphenol compound) as in table 3.

Table 3 Investigation of Active chemical compounds of Plantago lanceolata aqueous extract

\begin{tabular}{|l|c|c|c|}
\hline \multicolumn{1}{|c|}{ Sample } & Test name & Reagent & Result \\
\hline $\begin{array}{l}\text { 1g. residue in } 100 \mathrm{ml} \\
\text { Ethanol50\% }\end{array}$ & Tannins & $\begin{array}{c}\text { Lead Acetate } \\
\text { !\%solution }\end{array}$ & ++ve \\
\hline $\begin{array}{l}\text { 1g. residue in } 100 \mathrm{ml} \\
\text { Ethanol50\% }\end{array}$ & Polysaccharides & Benedict reagent \\
\hline $\begin{array}{l}\text { 1g. residue in } 100 \mathrm{ml} \\
\text { Ethanol50\% }\end{array}$ & Alkaloids & Dragangroff reagent & + ++ve \\
\hline $\begin{array}{l}\text { 1g. residue in } 100 \mathrm{ml} \\
\text { Ethanol50\% }\end{array}$ & Saponins & Foam formation & -ve \\
\hline $\begin{array}{l}\text { 1g. residue in } 100 \mathrm{ml} \\
\text { Ethanol50\% }\end{array}$ & Flavonoids & $\begin{array}{c}\text { Alkaline reagent } \\
\text { (NaOH) }\end{array}$ & +ve \\
\hline $\begin{array}{l}\text { 1g. residue in } 100 \mathrm{ml} \\
\text { Ethanol50\% }\end{array}$ & $\begin{array}{c}\text { Polyphenolic } \\
\text { Compounds }\end{array}$ & $\begin{array}{c}\text { ferric chloride } \\
3 \% \text { solution }\end{array}$ & ++ ve \\
\hline
\end{tabular}

\subsection{Reductive ability}

At six concentration have been tested $(0.02,0.04,0.08,0.16,0.32$ and $0.64 \mathrm{mg} / \mathrm{ml})$, of $P$. lanceolata aqueous plant extract then absorbance was matured that presented significantly increase in $0.64 \mathrm{mg} / \mathrm{ml}(0.272467 \pm 0.005033)$ while $0.124167 \pm 0.016073$ in $0.02 \mathrm{mg} / \mathrm{ml}$ and such finding showed that the plant aqueous extract is more effective than trolox slandered in the scavenger of free radicals.

Table 4 Reductive ability of Plantago lanceolata aqueous extract and trolox (vitamin E)-

\begin{tabular}{|l|c|c|}
\hline \multirow{2}{*}{$\begin{array}{c}\text { Con. } \\
(\mathrm{mg} / \mathrm{ml})\end{array}$} & \multicolumn{2}{|c|}{ Abso. (Mean \pm SD) } \\
\cline { 2 - 3 } & Plantago lanceolata & Trolox (Vitamin E) \\
\hline 0.64 & $0.272467 \pm 0.005033^{\mathrm{A}}$ & $0.211 \pm 0.015^{\mathrm{A}}$ \\
\hline 0.32 & $0.188167 \pm 0.007638^{\mathrm{B}}$ & $0.132 \pm 0.007^{\mathrm{B}}$ \\
\hline 0.16 & $0.173100 \pm 0.008718^{\mathrm{C}}$ & $0.114 \pm 0.004^{\mathrm{C}}$ \\
\hline 0.08 & $0.158600 \pm 0.009539^{\mathrm{D}}$ & $0.108 \pm 0.001^{\mathrm{CD}}$ \\
\hline 0.04 & $0.143980 \pm 0.004703^{\mathrm{E}}$ & $0.101 \pm 0.001^{\mathrm{CD}}$ \\
\hline 0.02 & $0.124167 \pm 0.016073^{\mathrm{F}}$ & $0.100 \pm 0.001^{\mathrm{D}}$ \\
\hline
\end{tabular}




\section{Hepatoprotective activity}

\subsection{Histopathological of liver}

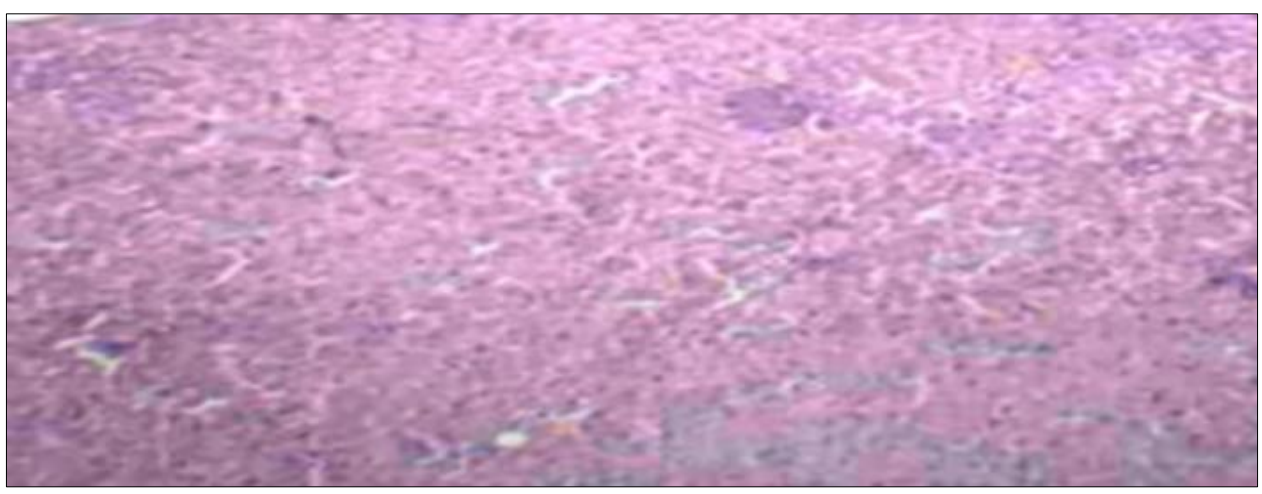

Figure 1 Section showing normal appearance of liver (H \& E)(X40)

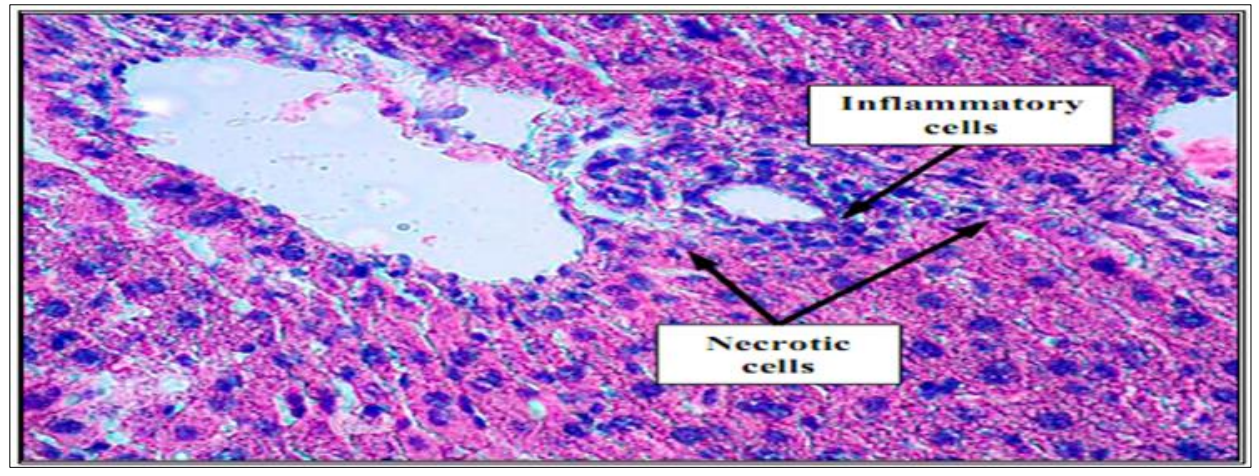

Figure 2 Necrosis is present together with mild inflammatory cell infiltrate (mononuclear cells) and fatty changes in liver tissue of mice treated with methotrexate drug (H \& E)(X40)

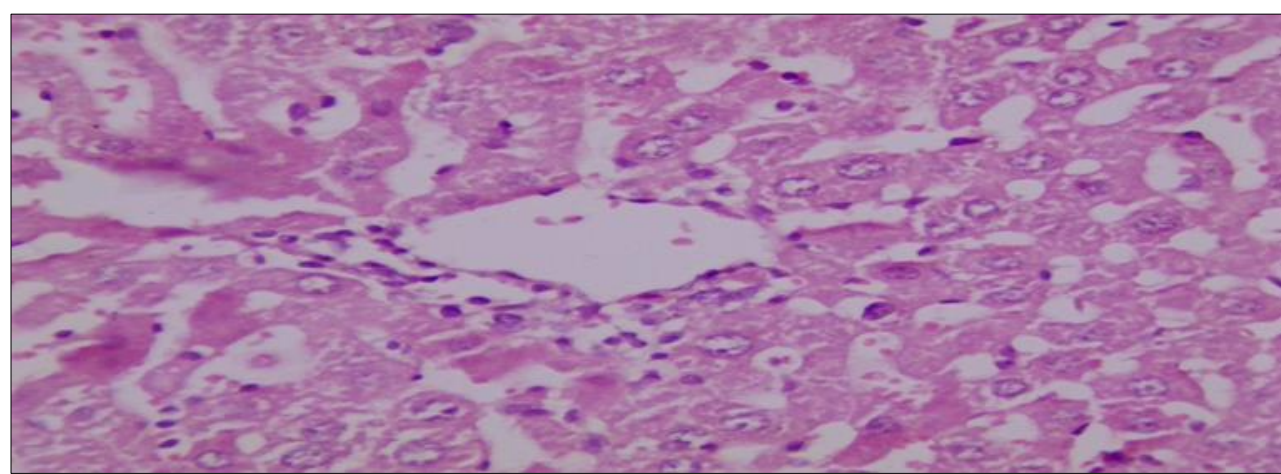

Figure 3 Degenerative changes, dispersed necrosis of hepatocyte, mild inflammatory cells infiltration, sinusoidal dilation and fatty changes in liver tissue of mice treated with plant extract. (H \& E)(X40) 


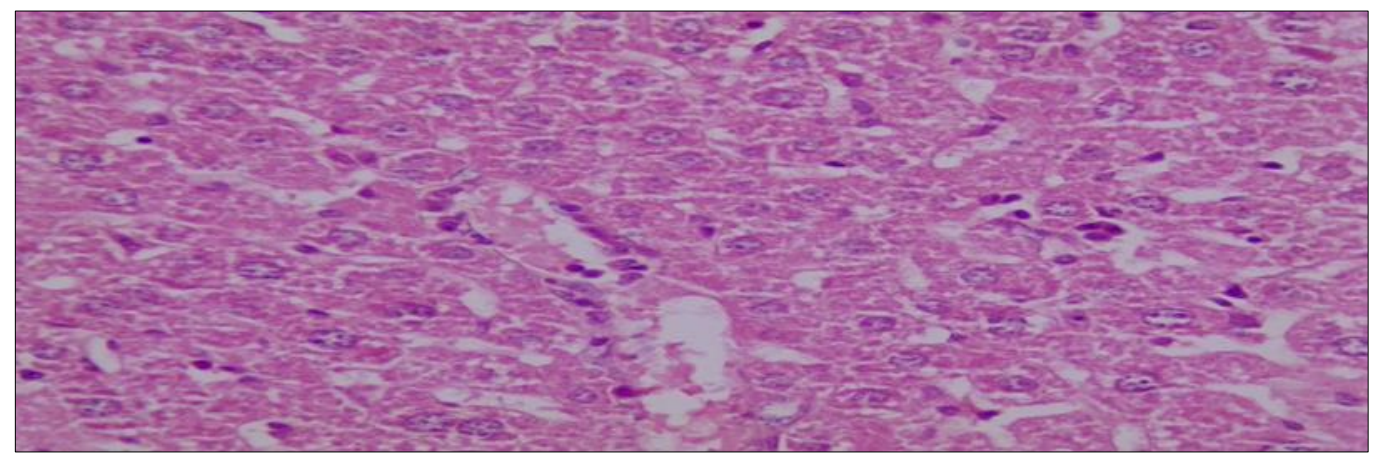

Figure 4 Look like near normal histological structure appearance but still there was dilatation of sinusoid in liver tissue of mice treated with plant extract and MTX. (H \& E)(X40)

\subsection{Liver enzyme}

Table 4 Liver enzymes of mice groups treated with Plantago lanceolata aqueous extract and interaction

\begin{tabular}{|l|l|l|l|}
\hline \multicolumn{1}{|c|}{ Groups } & GOT & GPT & ALP \\
\hline Distilled water & 396 & 146 & 179 \\
\hline Methotrexate & 214 & 77 & 92 \\
\hline Plantago lanceolata & 149 & 42 & 118 \\
\hline Methotrexate + plantago plant & 305 & 39 & 91 \\
\hline
\end{tabular}

Results for liver function enzymes showed the ability of plant to reduce the level of GOT, GPT and ALP. (149, 42 and 118 $\mathrm{U} \backslash \mathrm{L})$, when it compare with control $(396,146$ and $179 \mathrm{U} / \mathrm{L})$ respectively.

Also, interactions between plant and MTX showed the ability of plant to modulating harmful effects of the drug (305,39 and $91 \mathrm{U} \backslash \mathrm{L})$ for GOT, GPT and ALP respectivily when it compare with control (396,146 and 179 U/L) respectively.

\section{Discussion}

Medicinal plants are used for ages to maintain and enhance health of human body infections. This is for "their availability and arguably efficacious state, therefore expect an alternative remedy nowadays.

The flavonoid and phenolic compounds are the chief pharmaceutical components of pharmaceutical plants. These compounds are considered as effective anti-oxidant sources to scavenger of free radicals. Additional studies shown that normal products for example flavonoids and phenolic have showed to be effective free radical scavengers and lipid peroxidation inhibitors [14], and may be, the best designated and best beneficial assets of every group of flavonoids was their capability to work as antioxidants; protective the body of human against Reactive Oxygen Species (ROS) [15]. Therefore, there is increasing attention in the improving health benefits of dietary flavonoids, and the present study existing such interest in such medicinal plant such as $P$. lanceolata for examining their anti-oxidant and radical scavenging activity $t$, because of its richness in flavonoids and phenolic compounds.

P. lanceolata had in their compounds like apigenin, balcalein and luteolin in addition to their products with the main compounds apigenin 6.8-di-C-glucoside and luteolin-7-Oglucuronide, luteolin-7-0-glucoside and 7-Oglucuronide-3'glucoside [16]. and among phenolic carboxylic acids could be mentioned: p-hydroxy benzoic acid, protocatechnic, gentisinic, chlorogenic and neochlorogenic acid and others. Inorganic ingredients that contain $1 \%$ salicylic acid and salts [17].

The free radicals could be cause diseases by lipid, protein peroxidation or by DNA damage inside the human body, many therapeutic plants extracts have antioxidant activities for scavenging these damaging compounds. It could be avoid free radicals from causes any disease in human. Phenols compounds that had been presented;in a;high quantity in plants and showed antioxidant activity [18]. 
Phenolic compound such as phenolic acids, flavonoids, lignin and tannins that are general compounds found in plant parts such as leaves, flower tissues, had strong antioxidant activity found in these plant had their ability to scavenger free radicles through its reductive activity [19].

Hepatoprotective effects considered as the main source of human deaths in the world, aqueous plant extract of $P$. lanceolata seed, enhance the hepatoprotective effect had been done by the levels of liver enzymes like alanine aminotransferase (ALT) and aspartate aminotransferase (AST) showed reduced [20].

A number of therapeutic plants have active elements and crude herbal extracts were investigated to test their possible protective probable activity against MTX (Methotrexate) induced renal and hepatic side effects disorders. Like (Rhein, chicoric acid, inulin, gallic acid, disomin, berberin) and other plant extracts were tested as an method preventing MTX toxicity by antioxidant and anti-inflammatory pathways [21].The results of the present study showing that Plantago lanceolata aqueous extract which had the activity in antioxidant and anti-inflammatory could effectively reduce MTXinduced hepatic injuries in mice.

\section{Conclusion}

Plantago laceolata considered as an herbal promising plant that have anti-oxidant ability for scavenging free radical in all concentrations tested, also the aqueous plant extract had different chemical composition of secondary metabolites that contain Tannins, polysaccharide, Alkaloids, Flavonoids and Polyphenolic Compounds. The plant extracts counteract the damage caused by methotrexate drug through the reduction in liver enzymes GOT, GPT and ALP in all groups of mice the results of interactions indicated the ability of plant to modulating harmful effects of the drug in liver and its enzymes,

\section{Compliance with ethical standards}

\section{Acknowledgments}

The author would like to thank all the authors who were involved in the research and compiled the results of this research.

\section{Disclosure of conflict of interest}

The author declare that they have no conflict of interest.

\section{Statement of ethical approval}

All procedures performed in studies involving animals participants were in accordance with the ethical standards of the institutional research and with the comparable ethical standards.

\section{References}

[1] Bond W, Davies G, Turne R. The biology and non-chemical control of Ribwort Plantain (Plantago lanceolata L.). 2007.

[2] Kubát K. Klíč ke květeně české republiky. Prague: Academia. 2002.

[3] Beara IN, Lesjak MM, Orcic DZ, Simin ND, Cetojevic-Simin DD, Bozin BN, Mimica-Dukic NM. Comparative analysis of phenolic profile, antioxidant, anti-inflammatory and cytotoxic activity of two closely-related plantain species: plantago altissima L. and plantago lanceolata L. LWT-Food Sci Technol. 2012.

[4] Huang DF, Ming-Yong Xie, Jun-Yi Yin, Shao-Ping Nie, Yong-Fu Tang, Xiao-Mei Xie, Chao Zhou. Immunomodulatory activity of the seeds of Plantago asiatica L. Journal of Ethnopharmacology. 2009; 124(3): 493-498.

[5] Miser-Salihoglu E, Akaydin G, Caliskan-Can E, Yardim-Akaydin S. Evalution of Antioxidant Activity of Various Herbal Folk Medicines. J. Nutr Food Sci. 2013; 3(5): 1-9.

[6] Nurgali K, Jagoe RT, Abalo R. Adverse effects of cancer chemotherapy: Anything new to improve tolerance and reduce sequelae? Front Pharmacol. 2018; 9: 245.

[7] Niedernhofer LJ, Daniels JS, Rouzer CA, Greene ER, Marnett LJ. Malondialdehyde, a Product of Lipid Peroxidation, Is Mutagenic in Human Cells. J Biol Chem. 2008; 278: 31426-31433. 
[8] Sakanaka S, Tachibana Y, Okada Y. Preparation and antioxidant properties of extracts of Japanese persimmon leaf tea (kakinoha-cha). Food chemistry. 2005; 89(4): 569-575.

[9] Richard j. Cannell, METHODS IN BIOTECHNOLOGY /Natural Products Isolation. 2000.

[10] Fu W, et al. Antioxidant, free radical scavenging, anti-inflammatory and hepatoprotective potential of the extract from Parathelypteris nipponica (Franch. et Sav.) Ching. Journal of ethnopharmacology. 2010; 130(3): 521-528.

[11] Varan G, Öncül S, Ercan A, Benito JM, Mellet CO, Bilensoy E. Cholesterol-Targeted Anticancer and Apoptotic Effects of Anionic and Polycationic Amphiphilic Cyclodextrin Nanoparticles. Journal of Pharmaceutical Sciences. 2016; 105(10): 3172-82.

[12] Al-Ezzy RM, Mohammed Hassan ZY, Al-Jumaili FTO. Hematological Toxic Effect and the Frequency of Micronucleus Formation of Different Doses of Cyproheptadine on Albino Male Mice Blood Picture. Iraqi Journal of Hematology. 2017; 37: 149-53.

[13] Cirak S, Arechavala-Gomeza V, Guglieri M, Feng L, Torelli S, Anthony K, et al. Exon skipping and dystrophin restoration in patients with Duchenne muscular dystrophy after systemic phosphorodiamidate morpholino oligomer treatment: an open-label, phase 2, dose-escalation study, Lancet. 2011; 378: 595-605.

[14] Egert S, Rimbach G. Which sources of flavonoids: complex diets or dietary supplements. Adv Nutr. 2011; 2: 8-14.

[15] Xiao J, Chen T, Cao H. Flavonoid glycosylation and biological benefits. Biotechnol Adv. 22 May 2014; S07349750(14): 00092-5.

[16] Kuhn MA, Winston D. Herbal therapy supplements a scientific traditional approach. 2000.

[17] Wichtl M. Herbal drugs and Phytopharmaceuticals. Stuttgart: Medpharm Scientific Publishers Gmb H. 2004.

[18] Cocetta G, et al. Methyl jasmonate affects phenolic metabolism and gene expression in blueberry (Vaccinium corymbosum). Physiologia plantarum. 2015; 153(2): 269-283.

[19] Khulood W Abbood, RMI, Ali H Ad'hiah. Antioxidant activity of Hypericum triquetrifolium Turra methanol extract in vitro. International Journal of Medicinal Plants (Photon). 2015; 108: 632-637.

[20] Türel I, Özbek H, Erten R, Öner AC, Cengiz N, Yilmaz O. Hepatoprotective and anti-inflammatory activities of Plantago major L. Indian J Pharmacol. 2009; 41: $120-4$.

[21] Stenholm A, Goransson U, Bohlin L. Bioassay-guided supercritical fluid extraction of cyclooxygenase-2 inhibiting substances in Plantago major L. Phytochem Anal. 2013; 24: 176-83. 